\title{
PHYSICAL INVESTMENT FINANCING: THE CASES OF POLAND AND LATVIA
}

\author{
Katarzyna Żak \\ The University of Economics in Katowice, Poland, katarzyna.zak@ue.katowice.pl
}

\begin{abstract}
The aim of the article is to present and compare the major sources of financing of physical investments in Poland and Latvia and to attempt to identify their determinants. The subject of the diagnosis is the corporate sector in Poland and i Latvia in the years 2005-2015. The article uses methodology, developed by C. Mayer, J. Corbett and T. Jenkinson, that is based on the net sources of finance. The financial data analysed in the article come from the capital and financial accounts, constituting the element of the integrated system of national accounts. Assuming that in a given period of time, the sources of finance (revenue) are equal to their use (expenditure), it is possible to estimate the structure of financing of physical investments in the corporate sector. The practical dimension of the analysis should be viewed as an indication for identifying changes in the area of financing of physical investments in enterprises in the two countries.
\end{abstract}

Keywords: physical investment financing; capital and financial accounts; Poland; Latvia

JEL Classification: G390

\section{Introduction}

One of the major drivers behind every economy is investment, including investment implemented by the corporate sector. Economic entities engage in investment activity as this is a prerequisite for their effective performance, stable market position and keeping up with the competition (Pastusiak, 2010). Literature identifies two major trends in defining investment. One - the monetary trend - perceived investments as the movement of money. This means that the material dimension of an investment is not emphasised, but investments are treated as the flow of funds involving outflows and inflows of capital. The physical trend, also referred to as material, highlights the necessity to achieve a material effect of a given investment. An important role in this approach is played by the balance sheet as the compilation of an entity's assets and sources of finance. According to the physical approach, turning capital into assets or using new capital is perceived as investment (Rogowski 2013).

A number of authors (Jajuga, Słoński 1997, Wypych, 2007, Rogowski, 2013) define investments as long-term, risk-carrying allocation of economic resources (as investment outlays) aimed at a future benefit. They highlight their characteristic features, such as:

- outlay (the allocation of own capital, usually at the cost of current consumption, and external capital through asset acquisition),

- benefit (the expected outcome of an investment),

- time (how long capital is engaged and how long it takes to achieve a benefit),

- risk (the chance of deviations from the expected value of planned outlays and costs, benefits from the time of capital engagement, the length of the lifecycle of an investment).

In terms of what an investment concerns, there are two major types of investments: physical investments (tangible assets and intangible assets, but those that carry ownership rights - licenses, trademarks and patents) and financial (capital) investments - in financial and capital market instruments (Towarnicka 2000). On the basis of the general definition of an investment, physical investments of enterprises are risk-carrying expenditures of an investor's funds (own and /or external) on creating and/or rebuilding of fixed tangible assets and currents assets in order to achieve expected benefits in the future. Physical investments are usually made with the view of long-term exploitation. 
Accordingly, managers have to manifest due diligence whilst planning investment outlays and the sources of their financing and they need to make projections for their financial and economic implications in the future.

The aim of this article is to present and compare the major sources of financing of physical investments in the corporate sector and to attempt to identify their determinants. The article uses the methodology of the net sources of financing proposed by Mayer.

The subject of the diagnosis is the corporate sector in Poland and Latvia in the years 2005-2015. The article presents the review of reference literature and the analysis was conducted based on the information from primary sources, that is, the national accounts of the two countries.

\section{Methodology}

The prerequisite for any investment, including a physical investment, is access to capital. Two sources can be indicated: equity capital and debt capital. Equity capital comprises funds at an enterprise's disposal contributed by its owners (e.g. retained profit, depreciation), whilst debt capital includes funds at an enterprise's disposal on a temporary basis provided by its creditors, for example, long-term bank loans, bonds and leasing (Sierpińska, Jachna 2004).

In order to compare two basic sources of finance for physical investments, the article applies the methodology of net sources of finance developed by Mayer $(1988,1990)$. Investments cause economic flows, creating economic value. Hence, it seems justified to ground research in financial flows. The methodology pioneered by Mayer applies the flows of funds, instead of their balances, correcting the gross sources of finance by their use in order to estimate a net contribution from banks, equity capital, commercial papers, trade credits and other instruments to the financing of the corporate sector (Suzuki, Cobham, 2005).

One of the universally available sources of data on the flow of funds in enterprises is the European System of National and Regional Accounts. It is used to estimate flows of funds to and from the domestic corporate sector as a whole (Corbett, Jenkinson, 1997). The European System of National and Regional Accounts (ESA 95) offers a coherent international methodological and accounting standard that can be used for in-depth analysis of an economy, its structure and links with other economies (Council Regulation (EC) No 2223/96 1.01). The strength of national accounting is the fact that the system is adjusted to market economy and verified in practice.

Figures used to estimate physical investments in the corporate sector were obtained from two accounts, out of four accounts recording the accumulation, that is, the capital account and the financial account, characterised briefly in Table 1.

Table 1. The capital and financial accounts (Source: own elaboration based on Samborski (2011) and Studia i analizy statystyczne (2016))

\begin{tabular}{|l|l|}
\hline Specification & Characteristic \\
\hline The capital & $\begin{array}{l}\text { It describes the changes in the value of non-financial assets held by institutional } \\
\text { entities. The aim of the accumulation accounts is to present the process of capital } \\
\text { transactions financing (i.e. investments and an increase in tangible working capital as } \\
\text { well as acquisition and disposition of financial assets and liabilities). The capital } \\
\text { account shows the acquisition of non-financial revenue and capital transfers for the } \\
\text { capital transactions financing. On the revenue side (the sources) (the changes in } \\
\text { liabilities and net worth) of the capital account are recorded as the net savings and } \\
\text { capital transfers. The growth of non-financial assets and depreciation of fixed assets } \\
\text { are recorded on the expenditures side (the uses) (i.e. the changes in assets) of the } \\
\text { capital account. The balancing item of the capital account is the net lending ( }+ \text { ) or the } \\
\text { net borrowing (-). }\end{array}$ \\
\hline The & $\begin{array}{l}\text { This account records the financial transactions of financial assets and liabilities that } \\
\text { occur between institutional entities and between these entities and abroad. The assets }\end{array}$ \\
\hline
\end{tabular}




\begin{tabular}{|l|l|}
\hline account & $\begin{array}{l}\text { changes side of this account records the acquisition of financial assets less their use, } \\
\text { that is, the increase in financial claims, whereas the liabilities changes side and net } \\
\text { worth records the incurrence of liabilities less their repayment, that is, the increase in } \\
\text { financial obligations. As it has already been mentioned, the financial account does } \\
\text { not have a balancing item, transferred to the next account; however, the net result of } \\
\text { this account and the net incurrence of liabilities less the net acquisition of financial } \\
\text { assets equal in values but with the opposite sign of the net receivables/payables - the } \\
\text { item balancing the capital account. }\end{array}$
\end{tabular}

The net result of the financial account (the net incurrence of liabilities less the net acquisition of financial assets) is equal in value but with the opposite sign, to the balancing item in the capital account (the net receivables/payables). This results from the fact that in a given period, the sources of finance in the corporate sector (revenues) are equal to their use (expenditure). Hence, based on the flow of funds account, it is possible to estimate the structure of financing in the corporate sector. We should remember that part of the funds raised by enterprises is contributed towards the accumulation of financial assets. In consequence, the identification of the sources of finance for physical investments involves subtracting the net acquisition of financial assets (an increase in financial claims) from the net incurrence of liabilities (an increase in financial obligations). The logic behind the estimation of the sources of finance for physical investments in the corporate sector is presented in Table 2.

Table 2. Flow of funds account (Source: own elaboration based on Samborski (2011))

\begin{tabular}{|c|c|}
\hline \multicolumn{2}{|c|}{ 'Net pay-off' method } \\
\hline Gross revenues (Gross sources) & Gross expenditure (Gross uses) \\
\hline 1. Gross saving & 9. Currency, deposits and loans \\
\hline 2. Loans & 10. Shares and other equity \\
\hline 3. Shares and other equity & 11. Securities other than shares \\
\hline 4. Securities other than shares & 12. Other accounts (receivable/payable) \\
\hline 5. Other accounts (receivable/payable) & 13. Capital transfers \\
\hline 6. Capital transfers & 14. Other(insurance technical reserve) \\
\hline 7. Other (insurance technical reserve) & 15. Gross capital formation \\
\hline 8. TOTAL REVENUES (TOTAL SOURCES) & 16. TOTAL EXPENDITURE (TOTAL USES) \\
\hline \multicolumn{2}{|c|}{ 'Net balance' method } \\
\hline Net sources & Net uses \\
\hline \multicolumn{2}{|l|}{ Internal (1) } \\
\hline \multicolumn{2}{|l|}{ Bank finance (2-9) } \\
\hline \multicolumn{2}{|l|}{ New equity $(3-10)$} \\
\hline \multicolumn{2}{|l|}{ Bonds (4-11) } \\
\hline \multicolumn{2}{|l|}{ Trade credit (5-12) } \\
\hline \multicolumn{2}{|l|}{ Capital transfers (6-13) } \\
\hline \multicolumn{2}{|l|}{ Other (7-14) } \\
\hline NET SOURCES (8-9-10-11-12-13-14) & PHYSICAL INVESTMENT (15) \\
\hline
\end{tabular}


payments + other receivable and payables except for trade credits and advance payments; other = technical and insurance reserves; currency and deposits $=$ currency and deposits + short-term loans + long-term loans; physical investment $=$ gross capital formation $=$ gross fixed capital formation + changes in inventories + changes in valuables

Following the logic presented in Table 2, we can determine the significance of different sources of finance used in financing physical investments in the corporate sector within a given period of time. This procedure, however, does not show how specific investment projects are financed in particular enterprises.

Diagnosis of the condition of non-financial corporations in Poland and Latvia. The evaluation of the economic condition and investment processes in Poland's and Latvia's corporate sectors was conducted based on the selected macro-economic indicators classified by Eurostat as key indicators (Table 3).

Table 3. Key indicators of non-financial corporations in Poland and Latvia, 2005-2015 (Source: own elaboration based on Eurostat Database (2017))

\begin{tabular}{|c|c|c|c|c|c|c|c|c|c|c|c|}
\hline \multirow{2}{*}{ Specification } & \multicolumn{11}{|l|}{ Year } \\
\hline & 2005 & 2006 & 2007 & 2008 & 2009 & 2010 & 2011 & 2012 & 2013 & 2014 & 2015 \\
\hline \multicolumn{12}{|l|}{ POLAND } \\
\hline Investment rate $(\%)$ & 23.24 & 24.89 & 27.61 & 27.68 & 23.87 & 21.16 & 21.84 & 21.67 & 21.55 & 22.10 & 22.59 \\
\hline Profit share (\%) & 48.53 & 49.30 & 47.79 & 46.10 & 50.33 & 49.43 & 49.95 & 50.09 & 50.39 & 50.25 & 51.78 \\
\hline $\begin{array}{l}\text { Gross return on capital } \\
\text { employed before taxes } \\
(\%)\end{array}$ & 26.04 & 25.54 & 22.97 & 25.08 & 27.61 & 27.68 & 30.34 & 28.87 & 28.09 & 28.03 & 30.53 \\
\hline $\begin{array}{l}\text { Net debt to income ratio } \\
\text { after taxes }(\%)\end{array}$ & 151.45 & 138.62 & 178.67 & 237.30 & 161.83 & 134.89 & 151.12 & 175.81 & 177.91 & 180.61 & 166.77 \\
\hline $\begin{array}{l}\text { Net return on equity after } \\
\text { taxes }(\%)\end{array}$ & 13.57 & 14.33 & 12.04 & 15.07 & 18.54 & 20.58 & 25.39 & 22.95 & 22.55 & 24.02 & 26.57 \\
\hline \multicolumn{12}{|l|}{ LATVIA } \\
\hline Investment rate $(\%)$ & 36.74 & 38.55 & 40.06 & 35.18 & 24.84 & 19.62 & 23.72 & 28.22 & 26.49 & 24.60 & 25.35 \\
\hline Profit share (\%) & 51.43 & 47.59 & 44.38 & 41.21 & 46.32 & 50.30 & 53.67 & 52.49 & 50.97 & 48.20 & 45.94 \\
\hline $\begin{array}{l}\text { Gross return on capital } \\
\text { employed before taxes } \\
(\%)\end{array}$ & 40.36 & 31.77 & 28.26 & 25.33 & 26.29 & 27.32 & 30.89 & 31.72 & 30.62 & 27.76 & : \\
\hline $\begin{array}{l}\text { Net debt to income ratio } \\
\text { after taxes }(\%)\end{array}$ & 181.21 & 278.70 & 344.44 & 599.31 & 488.34 & 439.08 & 321.30 & 268.98 & 246.11 & 302.59 & : \\
\hline $\begin{array}{l}\text { Net return on equity after } \\
\text { taxes }(\%)\end{array}$ & 44.30 & 31.55 & 26.97 & 18.08 & 26.23 & 27.62 & 35.89 & 29.39 & 27.13 & 24.44 & 22.92 \\
\hline
\end{tabular}

The gross investment rate of non-financial corporations is defined as gross fixed capital formation divided by gross value added. This ratio relates the investment of non-financial businesses in fixed assets (buildings, machinery etc.) to the value added created during the production process. The gross investment rate in Poland's corporate sector in the years 2005-2015, except for 2010, remained significantly below the values observed in the Latvian economy in the same period. The average share of gross expenditure on fixed assets in gross value added stood at $23.4 \%$. In the years $2005-2008$, there was a growing trend concerning in this area, which peaked at $27.68 \%$ in 2008 . The consequence of the global financial crisis was a drop in 2009 - to $23.87 \%$, the lowest value, however, was reported 
in 2013 - at $21.55 \%$. In Latvia, the years $2005-2007$ saw a steady growth in the investment rate, reaching the peak of $40.06 \%$ in 2007 , only to fall to $24-25 \%$ in the years $2008-2015$. The lowest value was reported in $2009-19.62 \%$, considerably lower than the average $(29.40 \%)$ in the country in the researched period of time.

The profit share of non-financial corporations is defined as gross operating surplus divided by gross value added. This profitability-type indicator shows the share of the value added created during the production process remunerating capital. In the years 2005-2015, the Polish sector of non-financial corporations reported a slightly higher value of the operational surplus share in gross value added, which was $49.54 \%$ compared to that of Latvia, which stood at $48.41 \%$. In Latvia, the indicator was volatile, whilst in Poland, it grew steadily starting in 2011.

A gross return on capital employed, before taxes, of non-financial corporations is defined as a gross operating surplus divided by major financial liabilities. The latter include currency and deposits, debt securities loans and equity and investment fund shares/units. The indicator is a measure of the effectiveness of capital allocation in an economy. In 2005-2015, Poland had an average share of a gross operating surplus in net financial liabilities at the level of $27.34 \%$. In the subsequent years, the indicator stayed high, exceeding 30\% in the years 2011 and 2015, which indicates the improvement in capital allocation in the corporate sector in Poland. In Latvia, the average rate of the indicator in 20052015 was $30.03 \%$, with the peak of $40.36 \%$ reported in 2005 and the trough of $25.33 \%$ in 2008 . In the years $2009-2012$, the indicator grew steadily to reach $31.72 \%$, only to fall to $27.76 \%$ in 2014 . The volatility of the indicator reveals the problems that Latvian corporation had with effective capital allocation.

A net debt-to-income ratio, after taxes, of non-financial corporations is defined as main financial liabilities divided by net entrepreneurial income less current taxes on income and wealth. Main financial liabilities include currency and deposits, debt securities and loans. The indicator shows the ability (or inability) of the corporate sector to pay its current obligations from operating activity. In 2005-2015, the net debt-to-income ratio, after taxes, was very volatile in Polish non-financial corporations. From 2010 to 2014 , it grew substantially from $134.98 \%$ to $180.61 \%$, which means a deterioration in the capacity of the corporate sector to pay current obligations from operating activity. The situation improved in 2015 when the ratio fell to $166.77 \%$, which is still relatively higher than that in 2010. In Latvian corporations, in turn, the ration increased in the years 2006-2008, reaching the peak at $599.31 \%$, only to fall gradually to $246.11 \%$ in 2013 , which was the lowest level in the researched period. It recovered in 2014 when it increased to $302.59 \%$.

A net return on equity, after taxes, of non-financial corporations is defined as net entrepreneurial income less current taxes on income and wealth divided by equity and investment fund shares/units, liabilities. In 2005 and 2006, the Polish corporate sector had a net return on equity, after taxes, of approximately $14 \%$. It fell to the lowest value of $12.04 \%$ in 2007 , whilst from 2008 , it started to grow to reach $26.57 \%$ in 2015 . This means the improved effectiveness of equity capital allocation in the corporate sector. In Latvia's corporate sector, the years 2005-2008 saw a steady decrease in a net return on equity, after taxes, from $44.30 \%$ to $18.08 \%$, the lowest value in the researched period. In $2009-2011$, the ratio gradually increased to reach $35.89 \%$, only to fall again over the subsequent years to $22.92 \%$ in 2015 .

\section{Results}

In the years 2005-2015, significant changes occurred in the ways of financing physical investments in the sector of non-financial corporations operating in Latvia (Table 4).

Table 4. Sources of financing of physical investments in Polish and Latvian non-financial corporations, 20052015 (Source: own elaboration based on Eurostat Database) 


\begin{tabular}{|l|l|l|l|l|l|l|l|l|l|l|l|l|}
\hline \multirow{2}{*}{ Specification } & \multicolumn{9}{|l|}{ Year } & \multicolumn{7}{|l|}{} \\
\cline { 2 - 12 } & 2005 & 2006 & 2007 & 2008 & 2009 & 2010 & 2011 & 2012 & 2013 & 2014 & 2015 \\
\hline POLAND & 121.81 & 110.37 & 85.04 & 102.53 & 146.68 & 143.86 & 138.18 & 141.03 & 157.87 & 142.77 & 151.63 \\
\hline Internal (\%) & -9.29 & 17.00 & 18.14 & 48.73 & -9.50 & -16.65 & 18.79 & 27.23 & 4.26 & 5.24 & 2.77 \\
\hline Bank finance (\%) & 9.43 & 22.21 & 34.48 & -12.20 & 7.34 & -16.41 & -13.14 & 19.98 & 8.14 & 0.00 & -8.44 \\
\hline New equity (\%) & -3.26 & -5.22 & 6.88 & -1.06 & -1.24 & 3.23 & 12.37 & 8.81 & 4.94 & 8.56 & 1.60 \\
\hline Bonds (\%) & -1.50 & -16.24 & 14.27 & 3.52 & 0.00 & 0.00 & 5.62 & -12.12 & 0.00 & -2.21 & 8.96 \\
\hline Trade credit (\%) & 5.43 & 7.04 & 4.77 & 6.27 & 11.07 & 5.98 & 5.47 & 9.61 & 11.39 & 6.98 & 13.63 \\
\hline Capital transfers (\%) & 0.00 & -0.01 & -0.01 & -0.01 & -0.01 & -1.32 & -1.27 & -0.01 & -1.29 & -1.10 & -0.01 \\
\hline Other (\%) & 64.61 & 41.18 & 44.27 & 48.94 & 161.77 & 175.61 & 130.90 & 122.10 & 125.12 & 136.82 & 133.18 \\
\hline LATVIA & 34.41 & 53.19 & 47.82 & 35.45 & -22.12 & -11.60 & 16.40 & -25.82 & -5.82 & -58.98 & 6.82 \\
\hline Internal (\%) & 0.00 & 8.36 & -16.18 & -4.76 & -3.02 & 9.96 & 70.22 & -41.17 & 11.53 & 12.75 & 18.94 \\
\hline Bank finance (\%) & 2.38 & 0.00 & -0.01 & -1.65 & -0.01 & -4.71 & -2.31 & 1.80 & 2.72 & 3.60 & 1.06 \\
\hline New equity (\%) & 21.64 & 12.28 & 24.89 & 9.50 & 29.34 & -10.56 & -2.46 & -6.62 & -45.15 & 61.65 & -16.44 \\
\hline Bonds (\%) & 4.23 & 4.62 & 4.51 & 2.74 & 16.91 & 24.57 & 9.59 & 9.23 & 7.11 & 13.73 & 8.67 \\
\hline Trade credit (\%) & -0.01 & 0.00 & -0.01 & 0.00 & -0.01 & 0.00 & 0.00 & 0.00 & 0.00 & 1.01 & 0.00 \\
\hline Capital transfers (\%) & & & & & & & & & \\
\hline Other (\%) & & & & & & & & & \\
\hline
\end{tabular}

In 2005-2008, internal financing remained on a relatively low level, ranging from $41 \%$ to $64 \%$, only to rise significantly, starting in 2009 , exceeding the level of $100 \%$. Internal financing was the highest in 2009 - at $161.7 \%$ - and in 2010 - at $175.61 \%$. Also in the subsequent years, 2011-2015, physical investments of Latvian non-financial corporations were predominantly financed from interval sources.

In Latvia, the way of financing physical investments is strongly correlated with the country's economic situation. In the economy of Latvia, one of the Baltic tigers, three periods can be differentiated: the economic boom (2004-2007), the economic downturn (2008-2010) and the economic recovery (after 2011), which is illustrated by the data in Table 3.

Latvia's economic boom was characterised with a high economic growth rate stemming mainly from strong domestic demand. In 2005-2008, Latvian corporations financed their physical investments from a variety of sources - both internal and external. The use of corporations' own capital was supported with bank loans. This was facilitated by the modern, restructured banking system developed with the involvement from foreign banks, Scandinavian in particular, and German capital. In late 2007, Latvia had 31 banks, including foreign subsidiaries. In 2005-2007, there was an increase in an annual inflation rate - from $6.2 \%$ to $10.1 \%$ - which contributed to the depreciation of the Latvian lats. In consequence, price competitiveness decreased and costs went up. At the same time, real interest rates remained relatively low, which translated into growing debt in both households and corporations. It should be emphasised that the majority of loans were granted in foreign currencies. Latvia, the fastest growing economy in Europe, until then started to feel the coming economic crisis, still unaware that it would strike the hardest blow to the economic growth in the EU member states (Gostomski 2014).

In 2008-2010, Latvia, similar to many other countries, was affected by an economic downturn caused by the global financial crisis. In 2009, its GDP fell to an all-time low - $14.3 \%$ down on the previous year - and the unemployment rate increased to almost $20 \%$. This was mainly caused by a fall in investment expenditure and a decrease in consumer consumption. Latvian banks reduced borrowing to both corporate and individual customers, which led to a fall in internal demand. It should be noted that in 2008, one of the largest Latvian banks - Parex Banka - faced a massive bank run and the withdrawn deposits were exchanged into foreign currencies. This state of affairs was attributed to the operations of the Swedish government, which offered substantial bailouts to its banks, also the ones present on 
the Latvian market. As a result, many customers of Parex Banka chose to transfer their deposits to those banks. Only thanks to the assistance from the Latvian government, which bailed out the bank in return for an 85\% stake, Parex avoided bankruptcy (Gostomski 2014, Havemann 2010).

From 2009, it could be observed that more loans were paid back rather than taken out by corporations. The weakness of the economy caused enormous payment backlogs, making it impossible to support the financing of corporate operations in Latvia with trade credit.

As a result of the outflow of foreign capital, Latvia had to resort to applying for international assistance, comprising funds acquired from the European Union, the International Monetary Fund, Nordic countries (Denmark, Estonia, Finland, Norway and Sweden), World Bank and the Bank for Reconstruction and Development. Aid was granted on condition that Latvian authorities agreed to implement rigorous austerity and corrective measures. In late 2008, the government adopted the Economic Stabilisation and Growth Revival Programme, which aimed to strengthen the financial sector, reduce fiscal imbalance and maintain the lats exchange rate within ERM II. The reforms and outside financial aid contributed to the recovery of the Latvian economy from the crisis, whilst from 2011, the major macroeconomic indicators started to improve. Another effect of the reforms was also Latvia's accession to the euro zone in 2014 (National Bank of Poland 2014).

The signs of recovery in the Latvian economy did not fully translate into the ways of financing physical investments of non-financial corporations. On the basis of the data presented in Table 4, it can be concluded that managers, who remembered the experiences of the economic crisis, preferred to use internal capital, whilst manifesting reluctance to acquire capital from other sources of financing. Payment backlogs and poor use of corporate bonds are still a problem in Latvia. Moreover, the shallow stock market in the country fails to play an important role in raising funds to finance investments, despite the occurrence of single events, for example, a rapid growth in the share price of the logistics company Ventspils Nafta (by nearly 200\% within several days in September 2015), following the announcement by the fuel concern Vitol informing about the acquisition of a 93\% stake in Ventspils Nafta for USD 80 billion.

Figure 1 presents the shares of internal financing and bank financing (as the second most important source of finance for physical investment) in the sector of non-financial corporations against the gross investment rate in Latvia's economy in the years 2005-2015.

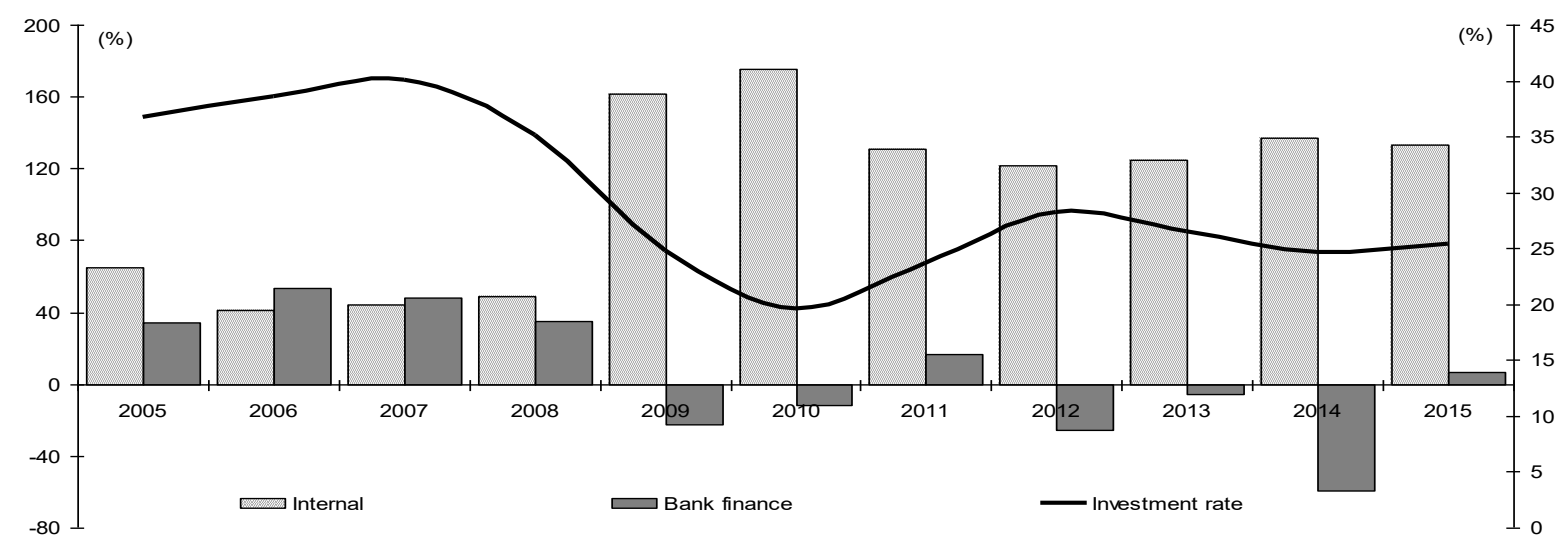

Fig. 1. Investment rate, internal and bank finance of Latvian non-financial corporations, 2005-2015

(Source: own elaboration based on the Eurostat Database)

Whilst discussing the situation in the Polish economy, it can be assumed that it went through the stages similar to the Latvian economy, that is, a growth stage, a slowdown stage and an economic recovery after 2011. Poland, similar to Latvia, struggled with the consequences of the world crisis in 2009 , but in the case of Latvia, a term often used is the overheating of the economy, whereas Poland went through the economic downturn more gently. 
On the basis of the data presented in Table 4, it can be stated that Poland's sector of non-financial corporations also tends to use internal financing more frequently than bank loans. In the researched period, only in 2007 , this value went below $100 \%$. In the other years, however, it exceeded $100 \%$, with a significant growth occurring after 2008 and lasting until 2015. It is worth to note that in the analysed period, the corporate sector experienced a considerable reduction in the gross investment rate. Weaker investment activity in the corporate sector was accompanied by a significant improvement in its performance. As a consequence, the period of the intensive restructuring of Poland's economy was followed by an increase in the share of internal financing sources in the structure of financing physical investments. Figure 2 shows the use of internal and bank financing of physical investments in Poland's sector of non-financial corporations against the investment rate.

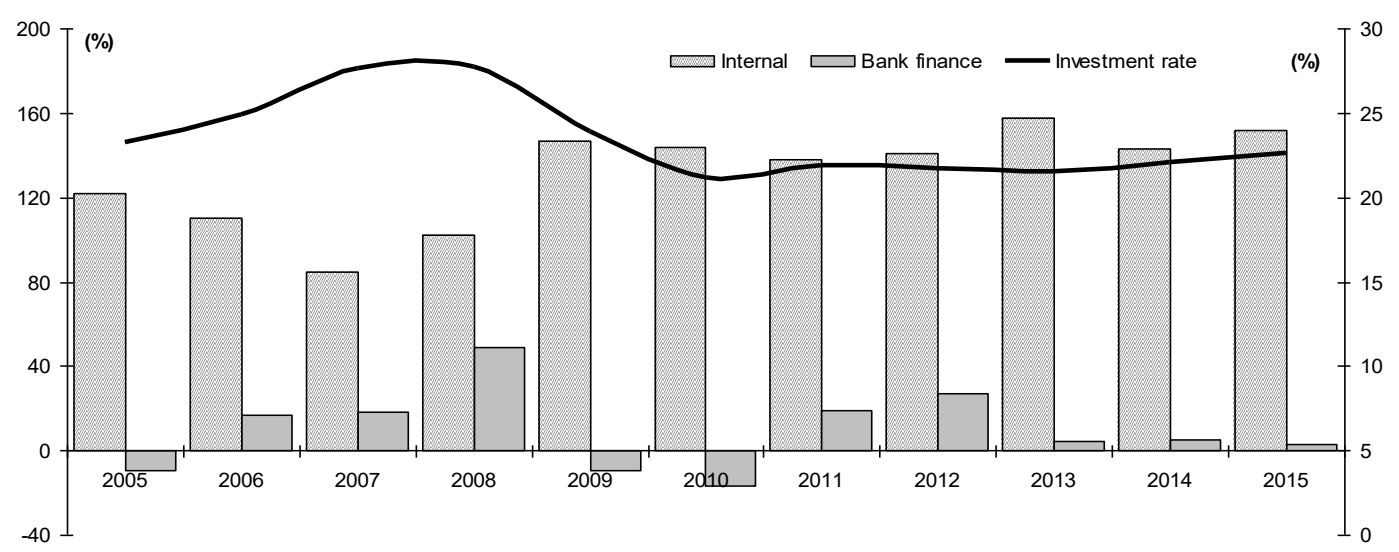

Fig. 2. Investment rate, internal and bank finance of Polish non-financial corporations, 2005-2015

(Source: own elaboration based on the Eurostat Database)

The Polish economy is dominated by small- and medium-sized enterprises, which by nature should support their growth with bank finance. Yet, in 2005 and 2009-2010, Polish businesses paid back more loans than they took out. It is estimated that approximately $20 \%$ of enterprises in Poland have not taken any loans for their entire period of operation. The data lead to a conclusion that a large number of enterprises operate - out of choice or necessity - without financing provided by bank loans. The survey conducted by the National Bank of Poland (Poland's central bank) revealed that the main reasons why enterprises were not interested in bank financing were their own sufficient resources and the use of non-bank finance. This means that financial security is more important for enterprises than the opportunity to take advantage of high positive leverage. More specific reasons for adopting the attitude of a discouraged borrower towards the possibility of obtaining a bank loan to support the growth of an enterprise can be identified as uncreditworthiness, high costs of a loan and unfavourable repayment conditions, a mismatch between a bank offer and the needs of an enterprise, overly complex procedures, the reluctance of enterprises to reveal their documentation, concerns related to credit terms, market uncertainty, bad experiences of cooperation with a bank and fear of the rejection of an application (Sawicka, Tymoczko, 2014).

In Poland, as in many other countries in the wake of the 2008 crisis, the banking sector attempted to implement favourable loan policies for enterprises by introducing low margins and applying more lenient risk assessment in particular sectors. Special programmes were pursued, aiming to encourage the use of bank finance, especially by the small- and medium-sized enterprise sector. In 2013, Poland's government launched a programme of guarantees, de minimis, targeting the SMS sector. Its main goals were (Sawicka, Tymoczko, 2014)

- offering loans to banks so that they can provide borrowing to enterprises,

- introducing a system of guarantees for enterprises applying for loans whilst not having collateral, 
- giving access to interest-free funds by the central bank to domestic banks in order to support borrowing targeted at small- and medium-sized enterprises,

- grating loans with reduced interest repayment to small- and medium-sized enterprises.

According to the representatives of banks, the programme of guarantees has helped to reach many enterprises that would not be granted a bank loan on commercial terms, which contributes to reduced borrowing discouragement, especially amongst small- and medium-sized businesses.

Considering the remaining sources of finance for physical investments, it should be stated that in Poland, capital acquisition from the stock exchange through the issuing of a corporation's shares plays a more important role than bond issues. Significant factors determining the volume of capital acquired through the issuing of securities on the stock exchange are the climate on the stock exchange and the size of investments planned by corporations. It should be added that Poland has an alternative to the issuing of bonds, which is - in addition to bank finance - the OTC corporate bond market, run by banks. Moreover, Poland's bond market is still relatively young, has limited liquidity and carries significant risk for investors.

The use of trade credit in supporting the growth of the corporate sector in Poland is stronger than that in Latvia, which does not mean that Polish corporations did not experience payment backlogs, the severity of which intensified in the years 2005-2006, 2012 and 2014.

\section{Conclusions}

The choice of the suitable source of capital used to finance investment is one of the crucial problems faced by corporations, especially that they can use a variety of ways of capital acquisition, depending on their needs and capabilities (share and bond issues, commercial papers, bank loans).

According to Meyer (1984) and his concept of the hierarchy of sources of finance, investment projects are first financed from internal and then from external sources.

The comparative study on the ways of financing physical investments in Poland's and Latvia's sectors of non-financial corporations confirms this theory. It should be additionally pointed out that the diversification (or its absence) of sources of financing growth depends, inter alia, on the differences between the economies in macroeconomic terms, the characteristics of a market financial system and factors typical of a given market (e.g. cost of capital), legal regulations, alternative methods of capital acquisition and their accessibility, including the role of a stock exchange, as sources of raising capital. Taking all these factors into account, it can be stated that:

- A macroeconomic situation, before, during and after the world crisis, significantly affected the way of financing physical investments by corporations in the two countries.

- Both Polish and Latvian corporations prefer financing based on internal sources. On the one hand, this was caused by limited investment activity during the crisis, which contributed to the accumulation of internal capital; on the other hand, internal capital is a safer source of finance.

- The reluctance of corporations to use bank finance was triggered by the condition of the banking sector and the terms of loan provision.

- Both Polish and Latvian corporations, in a limited scope, finance physical investments through the stock or bond market.

- Trade credit, which is not a primary source of financing investment, also did not play a positive role. The threat that in the Latvian corporate sector, long-term payment backlogs may contribute to many bankruptcies exists.

Putting aside the size of the countries, the number of corporations and the share of particular sectors in the growth of the national economies, it should be stated that what the countries have in common is the fact that both Poland and Latvia have been in transition towards market economy since the early 1990s. The corporations in the two countries face new prospects of financing their growth. There are 
grounds for optimism as recent years have seen the activity of the banking sector aiming to stimulate borrowing amongst corporations. Additionally, the EU membership of the two countries gives them more opportunity with respect to the freedom of capital flows. Finally, initiatives pursuing the strengthening of the stock exchanges as the markets for acquiring funds for investment activity also play a significant role.

\section{References}

Corbett J., Jenkinson T. (1997). How is investment financed? A study of Germany, Japan, the United Kingdom and the United States. The Manchester School Supplement, Oxford: Blackwell Publishers Ltd., pp. 69-93.

EUROSTAT DATEBASE: Key indicators by country, [Accessed March 2017]. Available from Internet: http://epp.eurostat.ec.europa.eu/portal/page/portal/sector_accounts/data/annual_dat

Gostomski E. (2014). Łotwy droga do strefy euro, Prace naukowe Uniwersytetu Ekonomicznego we Wrocławiu, Wrocław: Wydawnictwo Uniwersytetu Ekonomicznego we Wrocławiu.

Havemann J. (2010). The Great Recession of 2008-09: Year In Review 2009. [Accessed March 2017]. Available from Internet: https://www.britannica.com

Jajuga, T., Słoński T. (1998). Finanse spótek. Dlugoterminowe decyzje inwestycyjne i finansowe. Wrocław: Wydawnictwo Akademii Ekonomicznej im. Oskara Langego we Wrocławiu.

Meyer S. (1984). The capital structure puzzle, „Journal of Finance” 1984, No. 39, pp. 575-592.

Mayer C. (1998). New issues in corporate finance. "European Economic Review", No. 32 (5), pp. 1169-1189

Mayer C. (1990). Financial systems, corporate finance and economic development. [in:] R. Hubbard (ed.), Asymmetric information, corporate finance and investment. National Bureau of Economic Research, New York, pp. 307-331.

NBP (2014). Przygotowania Łotwy do czlonkostwa $w$ strefie euro $i$ pierwsze doświadczenia zwiazane $z$ wprowadzeniem wspólnej waluty, Warszawa: Narodowy Bank Polski. [Accessed March 2017]. Available from Internet: https://www.nbp.pl/cie/download/Ksiazka_Lotwawstrefieeuro_2014-PK_v2.9.pdf

Ostrowska E. (1999). Ryzyko inwestycyjne, Gdańsk: Wydawnictwo Uniwersytetu Gdańskiego.

Pastusiak, R. (2010). Ocena Efektywności Inwestycji. Warszawa: Wydawnictwo CeDeWu.

Rogowski W. (2013). Rachunek efektywności inwestycji. Warszawa: Wolters Kluwer.

Rozporządzenie Rady (WE) Nr 2223/96, 1.01 (1996). [Accessed March 2017]. Available from Internet: http://ec.europa.eu/enlargement/ccvista/pl/31996r2223-pl.doc

Samborski A. (2011). Wykorzystanie rachunków narodowych $w$ analizach ekonomicznych. [w:] W. Czakon (red.), Podstawy metodologii badań w naukach o zarządzaniu, Warszawa: Oficyna Wolters Kluwer business.

Sawicka A., Tymoczko I. (2014). Dlaczego polskie przedsiębiorstwa nie korzystaja z kredytu? Warszawa: Instytut Ekonomiczny Narodowego Banku Polskiego, pp. 29 and further.

Studia i analizy statystyczne (2016). Rachunki narodowe wedlug sektorów i podsektorów instytucjonalnych w latach 2011-2014. Warszawa: Wydawnictwo Głównego Urzędu Statystycznego, p. 9. [Accessed March 2017]. Available from Internet: http://stat.gov.pl/obszary-tematyczne/rachunki-narodowe/roczne-rachunki-narodowe

Suzuki K., Cobham D. (2005). Recent trends in the sources of finance for Japanese firms: has Japan become a 'high internal finance' country. Scotland: Discussion Paper Series, No. 0501, University of St Andrews, p. 1.

Towarnicka H. (2000). Strategia inwestycyjna przedsiębiorstwa, Wrocław: Wydawnictwo Akademii Ekonomicznej we Wrocławiu.

Wypych, M. (ed.). (2007). Finanse przedsiębiorstwa $z$ elementami zarzadzania $i$ analizy. Łódź: Wydawca: Absolwent Sp. z o.o. 